\title{
A Study of Relationships between Academic Self Concepts, Some Selected Variables and Physics Course Achievement
}

\author{
Medine Baran (Corresponding author) \\ Ziya Gokalp Education Faculty, Department of Physics \\ Dicle University, Diyarbakır, Turkey
}

Tel: 90-412-248-8820 E-mail: medinebaran@dicle.edu.tr

\begin{abstract}
A.Kadir Maskan
Ziya Gokalp Education Faculty, Department of Physics

Dicle University, Diyarbakır, Turkey
\end{abstract}

Tel: 90-412-248-8905_E-mail:akmaskan@gmail.com

\begin{abstract}
The aim of this study was to investigate the relationship between students' academic self concepts and certain variables (type of school, gender, financial state of the family, educational background of the parents, a computer available for use at home and the number of siblings) and the relationship between academic self concepts and students' achievement in the course of physics. The study was carried out with high school students $(n=396)$. In the study, the data were collected through the Academic Self Concept scale (the reliability coefficient of the scale was calculated by the researchers as 0.92 ), achievement scores in the course of physics and a questionnaire for the demographic background of the participants. Descriptive statistics, Independent samples t-test, Correlation analysis, Anova and Scheffe tests were used to analyze the data. The analysis of the data revealed that the computational ability sub-dimension mean scores of the students attending the vocational high school were lower than those of the students attending other schools. Moreover, significant relationships and differences were found in students' academic self concepts with respect to gender, parental education, financial state of the family and availability of a computer at home. In the study, positive relationships were found between students' achievement in the course of physics and the sub-dimension of interest in science.
\end{abstract}

Keywords: Academic Self Concept, Achievement, Demografic informations, High school students 


\section{Introduction}

It is known that such several factors as intelligence, achievement, human relations, social skills and the self influence human behavior. The self concept has a determinant role on human behavior and is alleged to be a different structure (Michelle \& Bracken, 1994). Researchers examined the self concept in three dimensions. These dimensions are examined under various headings such as social self, material self, spiritual self, professional self, real self, ideal self and academic self (Bacanl1, 1997). However, researchers focus more on the self concept in terms of the dimension of education. Academic self concept is defined as the belief of a student about how more talented he or she feels himself or herself than other students in terms of a certain academic activity (Arseven, 1979). Similarly, researchers define academic self concept as the degree of an individual's perception of his or her own proficiency in academic subjects (Bong \& Skaalvik, 2003; DiPerna \& Elliott, 1999). Environmental factors play an important role in the development of academic self concept. Environmental factors not only influence a number of affective domains of an individual living in harmony with the environment from birth but also affect the development of academic self concept. In this respect, the demographic features of the individual are of great significance. Studies carried out revealed that there was a relationship between the academic self concept of an individual and environmental factors such as the individual's gender, educational background of the parents, financial state of the family and the type of school (Pehlivan, 2010; Karasakaloğlu \& Saracaloğlu, 2009). The academic self concept, one of the affective features is another important factor that influences the learning processes and thus learners' achievement. In order for a person to make a decision on a subject, it is first necessary for him or her to know what he or she wants and what sources (abilities, financial means and environmental support) he or she has in hand. A student with a correct, realistic and rich self concept is more likely to make the right decision on choosing the courses and school appropriate to his or her abilities and interests. In this respect, it is possible to establish a connection between academic self concept and academic achievement. This relationship was found in a number of studies (Eccles \& Wigfield, 1995; Helmke \& Van Aken, 1995; Yeung \& Lee, 1999). Marsh, Hau and Kong (2002) reported that academic self and academic achievement influences each other mutually and that an increase in achievement leads to a strong academic self concept and an increase in academic self causes an important increase in achievement. As Beaman (2009) transferred:

In recent years, research suggests that positive academic self-concept demonstrates a causal effect on academic achievement (Marsh, 1987; Shavelson \& Bolus, 1982; Marsh, Byrne \& Yeung, 1999).

The present study is thought to be important as it aims at determining the relationships and differences between the academic self concepts of $11^{\text {th }}$ grade students - attending different types of schools - and certain variables (gender, school type, number of siblings, educational background of the parents, financial state of the family and availability of a computer at home) and their achievement in the course of physics. 


\section{1) Macrothink}

\section{Method}

\subsection{Participants}

A total of 396 students attending four types of schools participated in the present study. Among the participants, 91 of them were from a science high school, 70 from a vocational high school, 155 from a general high school and 80 from an Anatolian high school. Of all the participating students, $60.4 \%$ of them $(n=239)$ were male, and $39.6 \%$ of them $(n=157)$ were female. The mean of the number of the siblings of the participating students was 4.84. Among the participating students, $57.3 \%$ of them $(n=227)$ had a computer available for their use at home, while $42.7 \%$ of them $(n=169)$ did not.

\subsection{Data collection tools}

In the study, the 45-item academic self concept scale developed by Senemoğlu (1989) and adapted to science education was used. The reliability coefficient of this scale was calculated as 0.92 (Table 1). Moreover, in order to determine the students' achievement in the course of physics, the yearly physics course achievement records of the students attending four different types of high schools were used. In addition, in order to find out the demographic background of the students, a 6-item questionnaire for demographic background was applied.

Table 1. Reliability coefficient of the sub-dimensions of the academic self concept scale

\begin{tabular}{|l|c|}
\hline Variable & Reliability coefficient \\
\hline Total & .92 \\
\hline Computational ability & .77 \\
\hline Interest in science & .72 \\
\hline Interest in mechanics & .84 \\
\hline Shape-space ability & .87 \\
\hline
\end{tabular}

\subsection{Data analysis}

The research data were analyzed with the SPSS 15.0 package program at the significance level of 0.05 and 0.01. For the analysis of the data Descriptive analysis, Anova, Scheffe test, Independent samples t-test and Pearson correlation coefficients test were used.

\section{Findings}

When Table 2 is examined, it is seen that there are significant positive relationships between the sub-dimensions of academic self concept. 
Table 2. The results of correlation analysis regarding the sub-dimensions of the academic self concept

\begin{tabular}{|c|c|c|c|c|}
\hline Variable & $\begin{array}{c}\text { Computational } \\
\text { ability }\end{array}$ & $\begin{array}{c}\text { Interest in } \\
\text { science }\end{array}$ & $\begin{array}{l}\text { Interest in } \\
\text { mechanics }\end{array}$ & $\begin{array}{c}\text { Shape-space } \\
\text { ability }\end{array}$ \\
\hline $\begin{array}{l}\text { Computational } \\
\text { ability }\end{array}$ & 1 &, $481(* *)$ &, $335(* *)$ &, $465(* *)$ \\
\hline $\begin{array}{l}\text { Interest in } \\
\text { science }\end{array}$ & ,481(**) & 1 &, $478(* *)$ &, $432(* *)$ \\
\hline $\begin{array}{l}\text { Interest in } \\
\text { mechanics }\end{array}$ &, $335(* *)$ &, $478(* *)$ & 1 &, $644(* *)$ \\
\hline $\begin{array}{l}\text { Shape-space } \\
\text { ability }\end{array}$ &, $465(* *)$ &, $432(* *)$ &, $644(* *)$ & 1 \\
\hline
\end{tabular}

** $\quad \mathrm{P}<.01$

Table 3. Comparison of the academic self concept scores of the students attending different types of high schools

\begin{tabular}{|c|c|c|c|c|c|c|}
\hline Variable & & $\begin{array}{l}\text { Sum of } \\
\text { squares }\end{array}$ & Df & $\begin{array}{l}\text { Mean } \\
\text { squares }\end{array}$ & $\mathrm{F}$ & $\mathrm{P}$ \\
\hline $\begin{array}{l}\text { Academic } \\
\text { average }\end{array}$ & $\begin{array}{l}\text { Between groups } \\
\text { Within groups } \\
\text { Total }\end{array}$ & $\begin{array}{l}1,623 \\
74,265 \\
75,888\end{array}$ & $\begin{array}{l}3 \\
392 \\
395\end{array}$ & $\begin{array}{l}, 541 \\
, 189\end{array}$ & 2,855 &, 037 \\
\hline $\begin{array}{l}\text { Computation } \\
\text { al ability }\end{array}$ & $\begin{array}{l}\text { Between groups } \\
\text { Within groups } \\
\text { Total }\end{array}$ & $\begin{array}{l}18,912 \\
95,758 \\
114,670\end{array}$ & $\begin{array}{l}3 \\
392 \\
395\end{array}$ & $\begin{array}{l}6,304 \\
, 244\end{array}$ & 25,807 & ,000 \\
\hline $\begin{array}{l}\text { Interest in } \\
\text { science }\end{array}$ & $\begin{array}{l}\text { Between groups } \\
\text { Within groups } \\
\text { Total }\end{array}$ & $\begin{array}{l}1,828 \\
117,278 \\
119,106\end{array}$ & $\begin{array}{l}3 \\
392 \\
395\end{array}$ & $\begin{array}{l}, 609 \\
, 299\end{array}$ & 2,036 & ,108 \\
\hline $\begin{array}{l}\text { Interest in } \\
\text { mechanics }\end{array}$ & $\begin{array}{l}\text { Between groups } \\
\text { Within groups } \\
\text { Total }\end{array}$ & $\begin{array}{l}1,503 \\
152,593 \\
154,096\end{array}$ & $\begin{array}{l}3 \\
392 \\
395\end{array}$ & $\begin{array}{l}, 501 \\
, 389\end{array}$ & 1,287 & ,278 \\
\hline $\begin{array}{l}\text { Shape-figure } \\
\text { ability }\end{array}$ & $\begin{array}{l}\text { Between groups } \\
\text { Within groups } \\
\text { Total }\end{array}$ & $\begin{array}{l}, 770 \\
110,385 \\
111,155\end{array}$ & $\begin{array}{l}3 \\
392 \\
395\end{array}$ & $\begin{array}{l}, 257 \\
, 282\end{array}$ & ,911 & ,435 \\
\hline
\end{tabular}

$\mathrm{P}<.05$

The results in Table 3 showed that there were significant differences between the students' computational ability sub-dimension mean scores and their academic self concept total score means in terms of high schools.

In Table 4, it is seen that there was a significant difference between the academic self total score means of the students attending the science high school and the vocational high school in favor of the science high school $(\mathrm{P}<.05)$. 
Table 4. Comparison of academic self concept mean scores in terms of high schools

\begin{tabular}{|l|l|l|l|l|}
\hline $\begin{array}{l}\text { (I) } \\
\text { School }\end{array}$ & $\begin{array}{l}\text { (J) } \\
\text { School }\end{array}$ & X - X & $\begin{array}{l}\text { Standard } \\
\text { error }\end{array}$ & P \\
\hline \multirow{4}{*}{1} & 2 &, $195\left(^{*}\right)$ &, 069 &, 050 \\
\cline { 2 - 5 } & 3 &, 045 &, 057 &, 891 \\
\cline { 2 - 5 } & 4 &, 057 &, 067 &, 867 \\
\hline \multirow{4}{*}{2} & 1 &,$- 195\left(^{*}\right)$ &, 069 &, 050 \\
\cline { 2 - 5 } & 3 &,- 149 &, 063 &, 131 \\
\cline { 2 - 5 } & 4 &,- 138 &, 071 &, 293 \\
\hline \multirow{4}{*}{3} & 1 &,- 045 &, 057 &, 891 \\
\cline { 2 - 5 } & 2 &, 149 &, 063 &, 131 \\
\cline { 2 - 5 } & 4 &, 011 &, 060 &, 998 \\
\hline \multirow{3}{*}{4} & 1 &,- 057 &, 067 &, 867 \\
\cline { 2 - 5 } & 2 &, 138 &, 071 &, 293 \\
\cline { 2 - 5 } & 3 &,- 011 &, 060 &, 998 \\
\hline
\end{tabular}

$\mathrm{P}<.05$

1: Science high school

2: Vocational high school 3: General high school 4: Anatolian high school

Table 5. Comparison of computational ability mean scores in terms of high schools

\begin{tabular}{|c|c|c|c|c|}
\hline $\begin{array}{l}\text { (I) } \\
\text { School }\end{array}$ & $\begin{array}{l}\text { (J) } \\
\text { School }\end{array}$ & $X-X^{\prime}$ & $\begin{array}{l}\text { Standard } \\
\text { error }\end{array}$ & $\mathrm{P}$ \\
\hline \multirow[t]{3}{*}{1} & 2 &, $643(*)$ &, 079 &, 000 \\
\hline & 3 &, 175 & ,065 &, 067 \\
\hline & 4 & ,064 & ,076 &, 869 \\
\hline \multirow[t]{3}{*}{2} & 1 &,$- 643(*)$ & ,079 &, 000 \\
\hline & 3 & $-467(*)$ & 071 &, 000 \\
\hline & 4 &,$- 578(*)$ & ,081 &, 000 \\
\hline \multirow[t]{3}{*}{3} & 1 &,- 175 &, 065 &, 067 \\
\hline & 2 &, $467(*)$ & 071 &, 000 \\
\hline & 4 &,- 111 & ,068 & ,446 \\
\hline \multirow[t]{3}{*}{4} & 1 &,- 064 & ,076 &, 869 \\
\hline & 2 &, $578(*)$ & ,081 &, 000 \\
\hline & 3 &, 111 & ,068 & ,446 \\
\hline
\end{tabular}

$\mathrm{P}<.05$

When Table 5 is examined, it is seen that there was a significant difference between the mean scores of students attending the vocational high school and those attending the other three high schools in favor of the students attending the other three high schools $(\mathrm{P}<.05)$. 
Table 6. Comparison of academic self concept mean scores according to gender

\begin{tabular}{|c|c|c|c|c|c|c|}
\hline Variable & Gender & $\mathrm{N}$ & $X$ & SS & $\mathrm{t}$ & $\mathrm{P}$ \\
\hline \multirow{2}{*}{$\begin{array}{l}\text { Academic } \\
\text { average }\end{array}$} & Female & 157 & 2,82 & ,403 & \multirow[b]{2}{*}{$-2,794$} & \multirow[t]{2}{*}{, 005} \\
\hline & Male & 239 & 2,95 & ,454 & & \\
\hline \multirow[t]{2}{*}{$\begin{array}{l}\text { Computational } \\
\text { ability }\end{array}$} & Female & 157 & 2,92 & ,510 & \multirow[t]{2}{*}{$-1,029$} & \multirow[t]{2}{*}{,304 } \\
\hline & Male & 239 & 2,98 & ,557 & & \\
\hline \multirow{2}{*}{$\begin{array}{l}\text { Interest in } \\
\text { science }\end{array}$} & Female & 157 & 2,85 & ,515 & \multirow[b]{2}{*}{, 012} & \multirow[t]{2}{*}{,990 } \\
\hline & Male & 239 & 2,85 & ,571 & & \\
\hline \multirow{2}{*}{$\begin{array}{l}\text { Interest in } \\
\text { mechanics }\end{array}$} & Female & 157 & 2,64 & ,598 & \multirow[b]{2}{*}{$-4,828$} & \multirow[t]{2}{*}{,000 } \\
\hline & Male & 239 & 2,94 & ,614 & & \\
\hline \multirow{2}{*}{$\begin{array}{l}\text { Shape-space } \\
\text { ability }\end{array}$} & Female & 157 & 2,93 & ,489 & \multirow[b]{2}{*}{$-1,802$} & \multirow[t]{2}{*}{072} \\
\hline & Male & 239 & 3,03 & ,554 & & \\
\hline
\end{tabular}

Table 6 showed that the male students' academic self concept total score means and their mean scores of the sub-dimension of interest in mechanics were higher than female students' mean scores $(\mathrm{P}<.05)$.

Table 7. Comparison of academic self concept mean scores according to availability of a computer at home

\begin{tabular}{|c|c|c|c|c|c|c|}
\hline Variable & Computer & $\mathrm{N}$ & $X$ & $\mathrm{SS}$ & $\mathrm{t}$ & $\mathrm{P}$ \\
\hline \multirow{2}{*}{$\begin{array}{l}\text { Academic } \\
\text { average }\end{array}$} & 1 & 169 & 2,88 & ,439 & \multirow{2}{*}{,- 561} & \multirow[t]{2}{*}{, 575} \\
\hline & 2 & 227 & 2,91 & , 438 & & \\
\hline \multirow{2}{*}{$\begin{array}{l}\text { Computational } \\
\text { ability }\end{array}$} & 1 & 169 & 2,92 & ,543 & \multirow{2}{*}{$\begin{array}{l}-1,14 \\
4\end{array}$} & \multirow[t]{2}{*}{,253 } \\
\hline & 2 & 227 & 2,98 &, 535 & & \\
\hline \multirow{2}{*}{$\begin{array}{l}\text { Interest in } \\
\text { science }\end{array}$} & 1 & 169 & 2,83 & ,525 & \multirow{2}{*}{,- 609} & \multirow[t]{2}{*}{,543 } \\
\hline & 2 & 227 & 2,86 & ,567 & & \\
\hline \multirow{2}{*}{$\begin{array}{l}\text { Interest in } \\
\text { mechanics }\end{array}$} & 1 & 169 & 2,80 & ,622 & \multirow{2}{*}{,- 692} & \multirow[t]{2}{*}{,489 } \\
\hline & 2 & 227 & 2,84 & ,627 & & \\
\hline \multirow{2}{*}{$\begin{array}{l}\text { Shape-space } \\
\text { ability }\end{array}$} & 1 & 169 & 2,99 & ,521 & \multirow{2}{*}{,- 048} & \multirow[t]{2}{*}{,961 } \\
\hline & 2 & 227 & 2,99 &, 539 & & \\
\hline
\end{tabular}

1: I have a computer at home,

2: I don't have a computer at home

When Table 7 is examined, it is seen that there is no significant difference among the sample group students' academic self concept mean scores with respect to the availability of a computer at home $(\mathrm{p}>.05)$. 


\section{Al Macrothink}

Table 8. Relationships between certain demographic features of the students and academic self concept and its sub-dimensions

\begin{tabular}{|l|l|l|l|l|}
\hline Variable & $\begin{array}{l}\text { Number of } \\
\text { siblings }\end{array}$ & $\begin{array}{l}\text { Maternal } \\
\text { education }\end{array}$ & $\begin{array}{l}\text { Paternal } \\
\text { education }\end{array}$ & Income \\
\hline $\begin{array}{l}\text { Academic } \\
\text { average }\end{array}$ &,$- 104(*)$ &, 034 &, 096 &, $100(*)$ \\
\hline $\begin{array}{l}\text { Computation } \\
\text { al ability }\end{array}$ &,$- 113(*)$ &, 076 &, $139\left(^{* *}\right)$ &, $168(* *)$ \\
\hline $\begin{array}{l}\text { Interest in } \\
\text { science }\end{array}$ &,- 057 &, 046 &, $112(*)$ &, 042 \\
\hline $\begin{array}{l}\text { Interest in } \\
\text { mechanics }\end{array}$ &,- 057 &,- 013 &, 045 &, 012 \\
\hline $\begin{array}{l}\text { Shape-space } \\
\text { ability }\end{array}$ &,- 096 &, 017 &, 051 &, $127(*)$ \\
\hline
\end{tabular}

$* * \mathrm{p}<.01 * \mathrm{p}<.05$

When Table 8 is examined, it is seen that there was a negative relationship between the number of siblings of the sample group students and their academic self concept total score means and computational ability sub-dimension. It is also seen that there was a positive relationship between the paternal educational background and the mean scores of interest in science, computational ability and academic self concept, between the financial state of the family and academic self total score means, the sub-dimension of shape-space ability and computational ability.

Table 9. Relationships between the students' academic self concept mean scores and physics achievement

\begin{tabular}{|l|l|}
\hline Variable & Achievement \\
\hline Academic average &, $167\left(^{* *}\right)$ \\
\hline Computational ability &, $364(* *)$ \\
\hline Interest in science &, $169\left(^{* *}\right)$ \\
\hline Interest in mechanics &,- 038 \\
\hline Shape-space ability &, 088 \\
\hline
\end{tabular}

$* * \mathrm{p}<.01$

When Table 9 is examined, it is seen that there was a positive significant relationship between the students' academic self total score means, the mean scores regarding the sub-dimension of computational ability, the sub-dimension of interest in science and their achievement in the course of physics.

\section{Discussion and Conclusion}

In the study carried out, when four different high schools were compared according to the variable of academic self concept, the students attending the vocational high school had the lowest level of computational ability mean scores. The academic self concept mean scores of 
the students attending the science high school were higher than those of the students attending the vocational high school. In addition, regarding the case in Diyarbakir in the study, the computational ability sub-dimension mean scores of the students attending the vocational high school were generally higher than those of the students attending the other three high schools. It was reported in other studies that students choose to attend vocational high schools because they are not sufficiently proficient in computational skills or because of professional concerns (Köksal, 2006; EARGED, 2008). As a support to this finding, in a study carried out with 329 elementary school teacher candidates by Karasakaloğlu and Saracaloğlu (2009), it was found out that the academic self concept scores of the teacher candidates differed significantly with respect to the type of the school they graduated from. In addition, when the academic self concepts of the students were examined according to the variable of gender, it was seen that the male students' academic self concept total score means and their mean scores regarding interest in mechanics were higher than those of the female students. In another study carried out with science school students, Pehlivan (2010) found out that the academic self concepts of the female students were stronger than those of the male students. Çakır, Şahin and Şahin (2000), in their study, found out that the variable of gender did not influence science academic self concept. The results of studies revealed no specific finding regarding the difference between academic self concepts in terms of gender. In the present study, the finding that male students were more interested in the sub-dimension of mechanics than female students could be said to be due to the socio-cultural structure of the society they live in. The reason for these differences could be the fact that jobs requiring mechanical proficiency are mostly regarded as men's and that students grow with this perception starting from early ages. In addition, the present study investigated how students' academic self concepts changed with respect to the availability of a computer at home. However, no relationship was found between the students' academic self concept mean scores and the availability of a computer at home. This finding could be said to demonstrate that because computers are used almost in every area of life, they do not play a determinant role in the development of self concept. In addition, a negative relationship was found between the number of siblings and academic self concept total score means, the sub-dimension of computational ability. It is thought that the mean number of siblings of the participating students was high when compared to the living conditions and standards in the region. Due to the increasing number of siblings, several negative factors - for example, the decrease in the degree of the parents' care of the child, conflicts between siblings and financial problems of the family - are likely to play a negative role in the development of the student's academic self concept. In addition, in a study carried out by Dinah (2004), the researcher concluded that academic self concept was not influenced by the number of siblings in the family. Considering the different features of the sample groups participating in previous studies, it is not unusual that the findings obtained are not similar to each other. In the study, a significant positive relationship was found between the paternal educational background and the mean scores of interest in science, computational ability and academic self concept. With the help of the increasing communicative ability of the father parallel to his educational background, his communication with and confidence in the child and the student's academic self concept as a reflection of this are all directly or indirectly related with the father's educational 
background. Similar to this study, Senler and Sungur (2009) investigated the relationship between the father's educational background and academic self concept. However, at the end of the study, the researchers found a negative relationship between the father's educational background and science academic self concept. Moreover, in this study, no significant relationship was found between the mother's educational background and academic self concept. In another study carried out by Pehlivan (2010), it was found that maternal educational background does not influence a student's academic self concept. Similarly, a significant positive relationship was found between the financial state of the family and academic self total, computational ability and shape-space ability mean scores. As the financial state of the family improves, the resources available for the student correspondingly increase. With these resources, students are more likely to show their capabilities. This is believed to help students demonstrate both their power of academic self concept and their current capabilities. In addition, Çakır, Şahin and Şahin (2000) found out that the socio-economic level does not have any relationship with the student's academic self concept. Wonell and Roth (1998) found inconsistency in their study investigating the relationship of self concepts with gender, age and other variables. When the relationship between the self concepts of the students participating in this study and their achievement in the course of physics was examined, a significant positive relationship was found between the students' academic self total score means, computational ability, the sub-dimension of interest in science and their achievement in the course of physics. Physics is a branch of science. Therefore, the significant positive relationship found between the participating students' achievement in the course of physics and their interest in science was not surprising. In addition, physics has a close relationship with mathematics. A student successful in the course of physics is expected to be skilled in the computational field as well. This significant relationship found in the study is believed to be usual. Oliver and Simpson (1988), in their study, investigated the influence of science academic self concept on achievement in science and found out that affective feature such as academic self concept has a strong relationship with achievement in science. Jen and Chien (2008), in their study, found that students with higher academic self-concept tend to be more succesfull in learning activities. Similarly, in another study carried out by Şahin (1994) with 80 4th grade students, the researcher found a strong positive relationship between elementary school students' achievement levels and academic self concepts. Pehlivan and Köseoğlu (2010), in their study with 322 science school students, a significant positive relationship was found between the students' achievement levels and academic self concepts. Another study conducted by Çakır, Şahin and Şahin (2000) focused on academic self concept and other variables that predict another affective feature of students - their attitudes. Another study carried out with 611 elementary school 6th grade students investigated the predictive power of their end-of-year grades and science academic self concept. The findings obtained in the study revealed that the students' end-of-year grades constituted the strongest predictor of science academic self concept.

\section{Suggestions}

The following suggestions could be put forward depending on the findings obtained in the study: 
1-As it is important to focus on students' achievement and capabilities in secondary school education, it should also be equally important to determine and recognize the features of their academic self concepts.

2- Regarding the objectives of the education given, it would be beneficial to determine the academic self concept sub-dimensions of students attending different types of high schools and to investigate the relationships with the departments they will attend.

3- For healthy training of individuals, when family factors are taken into consideration, it would be beneficial to develop school-family relationships and to raise families' consciousness of students' affective features such as academic self concept.

4- Considering the relationship between achievement in the course of physics and academic self concept and its sub-dimensions, teachers of physics in secondary education could design their lesson plans in a way to improve students' academic self concept.

5- It would be beneficial to investigate the influence of such factors as the educational background of parents, financial state of the family, the technologies resources available at home and the number of siblings in the family on academic achievement and academic self concept in other fields and in different educational grades.

\section{References}

Arseven, D. A. (1979). Akademik benlik tasarımı ile akademik başarı arasindaki ilişki konusunda bir inceleme. Yayınlanmamiş doçentlik tezi. Ankara: Hacettepe Üniversitesi.

Bacanlı, H. (1997). Sosyal ilişkilerde benlik: Kendini ayarlamanın psikolojisi. İstanbul: Milli Eğitim Basımevi.

Beaman, V.A. (2009). The effects of grouping and curriculum on the self-concept of gifted children. Graduate thesis, submitted to the faculty of the school psychology department college of liberal arts, Rochester Institute of Technology.

Bong, M., \& Skaalvik E.M. (2003). Academic self-concept and self-efficacy: How different are they really? Educational Psychology Review, 15 (1), 1-40.

Çakır, Ö.S., Şahin, T., \& Şahin, B. (2000). İlköğretim 6. sınıf fen bilgisi dersinde çeşitli değişkenlerin öğrencilerin duyuşsal alanlarini açiklama gücü. Hacettepe Üniversitesi Ĕgitim Fakültesi Dergisi, 19, 43-49

Dinah, M. M. (2004). The relationship between a disadvantaged home environment and the self-concept of children: A Guidance and Counselling Perspective. Ph. D. Thesis in Psychology of Education, University of South Africa.

DiPerna, J. C., \& Elliott, S. N. (1999). Development and validation of the academic competence evaluation scales. Educational Psychology Review, 17, 207-225.

EARGED. (2008). Endüstri meslek lisesi ve teknik lise öğrencilerinin öss başarisindaki düşüş nedenleri. Available:http://earged.meb.gov.tr/tamamlanan/eml_oss_basarisi.pdf (February 2, 2011). 
Eccles, J. S., \& Wigfield, A. (1995). In the mind of the actor: The structure of adolescents' achievement task values and expectancy-related beliefs. Personality and Social Psychology Bulletin, 21, 215-225.

Helmke, A., \& Van Aken, M. A. G. (1995). The causal ordering of academic achievement and self-concept of ability during elementary school: A longitudinal study. Journal of Educational Psychology, 87, 624-637.

Jen T. H., \& Chien, C.L. (2008). The Influences of the Academic Self-concept on Academic Achievement: From a Perspective of Learning Motivation (Draft). The Proceedings of IRC. $1-8$.

Karasakaloğlu, N., \& Saracaloğlu, A.S. (2009). Sınıf öğretmeni adaylarinin türkçe derslerine yönelik tutumları, akademik benlik tasarimlari ile başarı arasındaki ilişki. Yüzüncü Yıl Üniversitesi, Eğitim Fakültesi Dergisi, 6 (1), 343-362.

Köksal, A. (2006). ÖSS öğrencilerinin sayısal derslerdeki başarısılık nedenlerinin araştırılmasının değerlendirilmesi. [Online] Avaliable: http://www.mufettisler.net/mesleki-calismalar/arastirmalar/33-ossde-sayisal-derslerde-basaris izlik-nedenleri-ali-koksal.html (January 19, 2011).

Kuzgun, Y. (2005). Akademik Benlik Kavramı Ölçeği El Kitabı. Ankara: Nobel Yayınları.

Marsh, H. W. (1987). The big-fish-little-pond effect on academic self-concept. Journal of Educational Psychology, 79, 280-95.

Marsh, H.W., Byrne, B.M., \& Yeung, A.S. (1999). Causal ordering of academic self-concept and achievement: Reanalysis of a pioneering study and revised recommendations. Educational Psychologist, 34, 155-167.

Marsh, H.W., Hau, K.T., \& Kong, C.K. (2002). Multilevel causal ordering of academic self concept and achievement: Influence of language of instruction (English compared with Chinese) for Hong Kong student. American Research Journal, 39 (3), 727-763.

Michelle, C. R., \& Bracken, B. A. (1994). Age, race and gender differences in child and adoleseem self-concept: evidence from a behavioral acpuisition, context-dependent model. School Psychology Review, 3, 496-511.

Oliver, J. S., \& Simpson, S. D. (1988). Influences of attitude toward science, achivement motivation and science self concept on achivement in science, a longitudinal study. Science Education, 72 (2), 143-155.

Pehlivan, H. (2010). Ankara fen lisesi öğrencilerinin matematik dersine yönelik tutumları ile akademik benlik tasarımlarının bazı ailesel faktörler açısından incelenmesi. Kastamonu Ĕ̆itim Dergisi, 18 (3), 805-818.

Pehlivan, H., \& Köseoğlu, P. (2010). Ankara fen lisesi öğrencilerinin biyoloji dersine yönelik tutumlari ile akademik benlik tasarimlari. Hacettepe Üniversitesi Eğitim Fakültesi Dergisi, 38, 225-235. 


\section{Macrothink}

Şahin, T. (1994). İlkokul 4. sınıf sosyal bilgiler dersinde akademik benlik kavramı, ders içi öğrenme ve ders dışı çalışma yolları ile başarı ilişkisi. Hacettepe Üniversitesi Ĕgitim Fakültesi Dergisi, 10, 43-48.

Senemoğlu, N. (1989). Öğrenci giriş nitelikleri ile öğretme-öğrenme süreci özelliklerinin matematik derslerindeki öğrenme düzeyini yordama gücü. Yayınlanmamış araştırma raporu. Ankara: Hacettepe Üniversitesi, Eğitim Fakültesi.

Senler, B., \& Sungur, S. (2009). Parental influences on students' self-concept, task value beliefs and achievement in science. The Spanish Journal of Psychology, 12 (1), 106-117.

Shavelson, R. J., \& Bolus, R. (1982). Self-concept: The interplay of theory and methods. Journal of Educational Psychology. 74(1), 3-17.

Worrell, F. C., \& Roth. D. A. (1998). Age and gender differences in the self-concept of academically talented students. Journal of Secondary Gifted Education, 9 (4), 157-163.

Yeung, A. S., Chui, H. S., \& Lau, I. C. Y. (1999). Hierarchical and multidimensional academic self-concept of commercial students. Contemporary Educational Psychology, 24, 376-389.

\section{Copyright Disclaimer}

Copyright reserved by the author(s).

This article is an open-access article distributed under the terms and conditions of the Creative Commons Attribution license (http://creativecommons.org/licenses/by/3.0/). 